\title{
The Control of Sulphate Activation in Bacteria
}

\author{
By J. F. WHELDRAKE AND C. A. PASTERNAK \\ Department of Biochemistry, University of Oxford
}

(Received 3 December 1964)

\begin{abstract}
1. ATP-sulphate adenylyltransferase (EC 2.7.7.4) and ATP-adenylyl sulphate 3'-phosphotransferase (EC 2.7.1.25) of Escherichia coli 9723, E. coli $\mathrm{K}_{12}$ and Bacillus subtilis 1379 are each repressed by growth in the presence of cystine. Repression of the two enzymes in $E$. coli 9723 may be co-ordinate. 2. ATP-sulphate adenylyltransferase of Desulphovibrio desulphuricans, in which sulphate reduction is linked to the energy supply of the organism, is not repressed by growth in the presence of inorganic sulphite or cysteine. 3. Leuconostoc mesenteroides lacks all the enzymes between sulphate and cysteine whether grown on cysteine or glutathione.
\end{abstract}

Sulphate activation is the first stage in the biosynthesis of cysteine by micro-organisms (Gregory \& Robbins, 1960; Wilson, 1962). In Escherichia coli and Bacillus subtilis the synthesis of the activating system that forms PAPS* from sulphate and ATP is repressed when cyst(e)ine is added to the growth medium (Pasternak, 1962). The two enzymes involved, ATP sulphurylase (ATP-sulphate adenylyltransferase, EC 2.7.7.4) and APS kinase (ATP-adenylyl sulphate $3^{\prime}$-phosphotransferase, EC 2.7.1.25), have now been examined separately (Pasternak, Crichton, Ellis, Jones-Mortimer \& Wheldrake, 1964) to determine whether one or both are repressed.

In some strict anaerobes such as Desulphovibrio desulphuricans the reductive pathway from sulphate to sulphide is not merely used for the production of cysteine but is the means by which the organism oxidizes carbon substrates to obtain energy for growth (Postgate, 1959). Repression of the enzyme forming active sulphate, which in this case is APS, not PAPS (Peck, 1959, 1962), would therefore limit growth. To test whether the synthesis of ATP sulphurylase is accordingly insensitive to repression, the enzyme has been assayed in extracts of $D$. desulphuricans grown in the presence of added cysteine or sulphite.

A third class of organism cannot synthesize cysteine at all. Leuconostoc mesenteroides, for example, has been shown to lack the final enzyme (EC 4.2.1.22) in the biosynthetic sequence (Brüggemann, Schlossmann, Merkenschlager \& Waldschmidt, 1962), but whether the other enzymes are also missing has not been determined. We have therefore measured ATP sulphurylase

* Abbreviations: APS, adenosine 5'-sulphatophosphate; PAPS, adenosine $3^{\prime}$-phosphate $5^{\prime}$-sulphatophosphate. and APS kinase, as well as PAPS reductase and sulphite reductase (EC 1.8.1.2), in $L$. mesenteroides grown on glutathione or cysteine.

\section{MATERIALS AND METHODS}

Chemicals. APS was prepared by the following method (Cherniak \& Davidson, 1964). To $700 \mathrm{mg}$. of dry AMP (trioctylammonium salt) were added $12 \mathrm{ml}$. of dioxan, $2 \mathrm{ml}$. of dimethylformamide and $1.1 \mathrm{ml}$. of pyridine, followed by $840 \mathrm{mg}$. of triethylamine- $N$-sulphonic acid, and the mixture was shaken overnight. Then $20 \mathrm{ml}$. of chloroform was added, the suspension extracted twice with $10 \mathrm{ml}$. of $0.05 \mathrm{~N}$ ammonia and the $\mathrm{pH}$ of the combined extracts rapidly adjusted to $6 \cdot 8$. This solution $(200 \mathrm{ml}$.) was chilled and adsorbed on a column $(15 \mathrm{~cm} . \times 3.5 \mathrm{~cm}$. diam.) of Dowex 1 (X4; $\mathrm{Cl}^{-}$form; 200-400 mesh), washed with water and eluted with a gradient achieved by allowing 21 . of $2 \mathrm{~m}-\mathrm{LiCl}$ to drip into a mixing vessel containing 31 . of water at $2.5 \mathrm{ml}$. $/ \mathrm{min}$. When 200 fractions $(10 \mathrm{ml}$. each) had been collected on an LKB RadiRac fraction collector (Gallenkamp and Co. Ltd., London, E.C.2) at $3^{\circ}$, the reservoir was refilled with $4 \mathrm{~m}-\mathrm{NaCl}$ and elution continued. The ultraviolet absorption of the effluent fractions was measured. The first peak (tubes 79-105) contained AMP and the second (tubes 250-285) APS. The $\mathrm{pH}$ of the combined APS fractions was adjusted to 6 with $\mathrm{HCl}$ and the solution adsorbed on a column $(15 \mathrm{~cm} . \times 2 \mathrm{~cm}$. diam.) of acid-washed Nuchar C charcoal at $3^{\circ}$; the column was washed with water and eluted with $300 \mathrm{ml}$. of ethanol-aq. ammonia (sp.gr. 0•88)water $(20: 1: 20$, by vol.). The eluate was concentrated to $100 \mathrm{ml}$. by rotary evaporation below $20^{\circ}$ and freeze-dried. The yield (in terms of the AMP salt) was $40 \%$. [35S]APS was prepared by incubating $250 \mu$ moles of ATP, $50 \mu$ moles of $\mathrm{Na}_{2}{ }^{35 \mathrm{SO}_{4}}(2 \mathrm{mc}), 100 \mu$ moles of $\mathrm{MgCl}_{2}, 30 \mu$ moles of EDTA, 5m-moles of tris-HCl buffer, $\mathrm{pH} \mathrm{8.5}$, and the supernatant fraction of an extract of $D$. desulphuricans (100-300 mg. of protein) or $E$. coli mutant $12 \mathrm{C}(50 \mathrm{mg}$. of protein) in a final volume of $50 \mathrm{ml}$. for $30 \mathrm{~min}$. The reaction was stopped by heating at $100^{\circ}$ for $1 \mathrm{~min}$., protein removed by centrifugation and the chilled supernatant diluted to 
$100 \mathrm{ml}$. and the $\mathrm{pH}$ adjusted to 6 with $\mathrm{HCl}$. The solution was adsorbed on a column $(10 \mathrm{~cm} . \times 1.5 \mathrm{~cm}$. diam.) of acidwashed Nuchar $\mathrm{C}$ charcoal at $3^{\circ}$; the column was washed with $50 \mathrm{ml}$. of $0 \cdot 1 \mathrm{M}-\mathrm{Na}_{2} \mathrm{SO}_{4}$ followed by water until the washings were free of radioactivity, eluted with $100 \mathrm{ml}$. of ethanol-aq. ammonia (sp.gr. 0·88)-water (20:1:20, by vol.) and the eluate concentrated to $5 \mathrm{ml}$. by rotary evaporation below $20^{\circ}$. The yield was $0.05-0.5 \mu$ mole. It was noticed during this work that neutral solutions of [35S]APS, unlike [35S]PAPS, are appreciably hydrolysed at temperatures above $0^{\circ}$. Reaction mixtures containing [35S]APS were analysed immediately after incubation.

Organisms and conditions of growth. E. coli A.T.C.C. 9723, $E$. coli $\mathrm{K}_{12} 701$ and $B$. subtilis N.C.T.C. 1379 were grown as described by Pasternak, Ellis, Jones-Mortimer \& Crichton (1965). B. subtilis N.C.T.C. 3610, obtained from the Chemical Microbiology Unit, University of Oxford, was grown in $1.3 \%(w / v)$ Oxoid nutrient broth $\mathrm{CM} 1$ or in the minimal medium of Pasternak (1962), each containing glucose (0.5\%). D. desulphuricans (N.C.I.B. 8303), obtained from the Torry Research Station, Aberdeen, was maintained in stab culture as described by Starkey (1938). Cultures were grown statically for 3-4 days at $37^{\circ}$ in medium C of Butlin, Adams \& Thomas (1949), modified by the omission of $\mathrm{Na}_{2} \mathrm{SO}_{4}$ and the substitution of $\mathrm{MgSO}_{4}$ by $0.5 \mathrm{~g}$. of $\mathrm{MgCl}_{2}, 6 \mathrm{H}_{2} \mathrm{O} / \mathrm{l}$; $\mathrm{Na}_{2} \mathrm{~S}$ was added before inoculation (Bornstein \& Barker, 1948). L. mesenteroides P60 (A.T.C.C. 7881), obtained from the Chemical Microbiology Unit, was grown statically overnight at $37^{\circ}$ in the medium of Gibson \& Woods (1960), except that cysteine was replaced by glutathione in some experiments. Mutants of $E$. coli 9723 and $E$. coli $\mathrm{K}_{12}$, obtained by ultraviolet irradiation, were enriched by the penicillin technique (Davis, 1948) followed by replication from cystine-containing to sulphate-containing agar plates. Mutants, characterized as described by Ellis, Humphries \& Pasternak (1964), were maintained on slopes of minimal medium containing cystine, and were grown in minimal medium (Pasternak, 1962) containing Difco yeast extract $(0 \cdot 004 \%)$. Bacteria were harvested and extracted as described by Ellis et al. (1964) and the supernatant fraction was used.

Enzyme assays. ATP sulphurylase could not be assayed satisfactorily. Molybdolysis (Wilson \& Bandurski, 1958) gave spurious results in that $E$. coli 4-2 grown on glutathione and $E$. coli 9723 grown on $0.42 \mathrm{~mm}$-L-cystine appeared to have up to $60 \%$ of the activity of $E$. coli 9723 grown on glutathione. However, when molybdate was added to extracts after incubation, the same amount of inorganic phosphate $(60 \%$ of the glutathione-grown wild-type) was released. Further experiments showed that molybdate displaces inorganic phosphate adsorbed to proteins. The best assay found for ATP sulphurylase consisted in adding $\mathrm{CuCl}_{2}(1.25 \mathrm{~mm})$ to the incubation mixture of Pasternak (1962). $\mathrm{Cu}^{2+}$ inhibits the metabolism of APS (cf. Balasubramanian \& Bachhawat, 1962), which therefore accumulates. However, ATP sulphurylase is also slightly inhibited $(0 \cdot 25 \mu$ mole of APS and $78 \mu$ moles of PAPS formed in the absence of $\mathrm{Cu}^{2+} ; 22 \cdot 2 \mu$ moles of APS and $0.4 \mu$ mole of PAPS formed in its presence). The incubation mixture (Pasternak, 1962) without $\mathrm{Cu}^{2+}$ was used to assay ATP sulphurylase in $E$. coli 12C and $D$. desulphuricans, which lack APS kinase. APS kinase was assayed by incubating $5 \mu$ moles of ATP, $5 \mu$ moles of $\mathrm{MgCl}_{2}, 0.5 \mu \mathrm{mole}$ of [ ${ }^{35 \mathrm{~S}}$ ]APS $(0.01 \mu \mathrm{C}), 25 \mu \mathrm{moles}$ of tris- $\mathrm{HCl}$ buffer, $\mathrm{pH} 8.5$, and enzyme extract in $0.45 \mathrm{ml}$. for
$30 \mathrm{~min}$. at $37^{\circ}$. The reaction was stopped by heating at $100^{\circ}$ for $2 \mathrm{~min}$., protein removed by centrifugation and a sample $(0 \cdot 05-0 \cdot 1 \mathrm{ml}$.) of the supernatant assayed by paper electrophoresis ([ $\left.{ }^{35 \mathrm{~S}}\right] \mathrm{APS},\left[{ }^{35 \mathrm{~S}}\right] \mathrm{PAPS}$ and ${ }^{35 \mathrm{SO}_{4}}{ }^{2-}$ are well separated by $15 \mathrm{v} / \mathrm{cm}$. for $2 \frac{1}{2} \mathrm{hr}$. in $0.1 \mathrm{M}$-ammonium acetate buffer, $\mathrm{pH5}$.6) and the radioactivity on the dried strips measured in a Radioactive Chromatogram Counter (Baird and Tatlock Ltd., Chadwell Heath, Essex) or a type 2029 chromatogram scanner operated automatically on stepwise drive (Isotope Developments Ltd., Beenham, Berks.).

Alternatively, unlabelled APS (1 $\mu$ mole) was incubated with $7 \cdot 5 \mu$ moles of ATP, 7.5 $\mu$ moles of $\mathrm{MgCl}_{2}, 200 \mu$ moles of tris-HCl buffer, pH8.5, and enzyme extract (3-4 mg. of protein) in a final volume of $2 \mathrm{ml}$. for $15 \mathrm{~min}$. at $37^{\circ}$. The reaction was stopped by heating at $100^{\circ}$ for $2 \mathrm{~min}$., protein removed by centrifugation and a sample $(0.1 \mathrm{ml}$.) of the supernatant analysed by paper electrophoresis. The area corresponding to PAPS was cut out, eluted with $1 \mathrm{mN}$ ammonia and the extinction at $257 \mathrm{~m} \mu$ measured. The formation of PAPS from sulphate and ATP was measured as described by Pasternak (1962). Protein was estimated by the method of Gornall, Bardawill \& David (1957), with bovine plasma albumin as standard.

\section{RESULTS AND DISCUSSION}

Control of sulphate activation in E. coli. Two sulphiteless mutants proved useful in these studies. Mutant 4-2, derived from $E$. coli 9723, was found to lack ATP sulphurylase, and mutant $12 \mathrm{C}$, derived from $E$. coli $\mathrm{K}_{12}$, was devoid of APS kinase (Table 1). All other enzymes of the biosynthetic pathway from sulphate to cysteine (Pasternak et al. 1965) were intact in these mutants. By mixing extracts of the mutants grown on glutathione with an extract of $E$. coli 9723 or $E$. coli $\mathrm{K}_{12}$ grown on cystine, it was shown that both the enzymes concerned with sulphate activation are repressed by cystine (Table 2 ). Since all $E$. coli extracts contain enzymes degrading APS and PAPS, mixing an active with an inactive extract decreases the expected yield. Similar results have been obtained by Monty (1964, and personal communication) with the sulphate-activating enzymes of Salmonella typhimurium. The two enzymes of $E$. coli 9723 were also assayed separately, as shown in Table 3. APS kinase appears to have a higher specific activity in crude extracts than has the overall conversion of sulphate into PAPS. This suggests that the first enzyme, ATP sulphurylase, is ratelimiting. Confirmation of this was obtained by adding an extract of mutant $12 \mathrm{C}$ grown on glutathione to extracts of $E$. coli 9723 grown on glutathione, sulphate, sulphite or a low concentration of cystine. In each case the specific activity of the overall conversion of sulphate into PAPS was increased to that of APS kinase. Table 3 shows that, within the limits of experimental error, the specific activity of ATP sulphurylase bears a constant ratio to that of APS kinase. Hence the two enzymes, 
Table 1. Characterization of two sulphiteless mutants of E. coli

Extracts of the mutants grown (0.1-0.4 mg. drywt. of cells/ml.) on glucose (0.1\%) plus glutathione (0.21 mM) or L-cystine $(0.42 \mathrm{~mm})$ were incubated with $3 \mu$ moles of ATP, $0.3 \mu$ mole of $\mathrm{Na}_{2}{ }^{35 \mathrm{SO}_{4}}(10 \mu \mathrm{C}), 3.75 \mu \mathrm{moles}$ of $\mathrm{MgCl}_{2}$ and $25 \mu$ moles of tris-HCl buffer, $\mathrm{pH} 8 \cdot 8$, in $0.4 \mathrm{ml}$. for $15 \mathrm{~min}$. and the products analysed by paper electrophoresis.

\begin{tabular}{|c|c|c|c|c|}
\hline Mutant & $\begin{array}{l}\text { S source for } \\
\text { growth }\end{array}$ & $\begin{array}{c}\text { Amount of } \\
\text { extract added } \\
\text { (mg. of protein) }\end{array}$ & $\begin{array}{l}\text { Yield of APS } \\
\text { (m } \mu \text { moles) }\end{array}$ & $\begin{array}{l}\text { Yield of PAPS } \\
\qquad(\mathrm{m} \mu \text { moles })\end{array}$ \\
\hline E. coli 4-2 & Glutathione & $1 \cdot 2$ & $<0.15$ & $<0.15$ \\
\hline E. coli 4-2 & L-Cystine & $1 \cdot 6$ & $<0.15$ & $<0.15$ \\
\hline E. coli 12C & Glutathione & $1 \cdot 0$ & $11 \cdot 4$ & $<0.15$ \\
\hline E. coli $12 \mathrm{C}$ & L-Cystine & $2 \cdot 6$ & $<0.15$ & $<0.15$ \\
\hline E. coli 4-2 & Glutathione & $1.2\}$ & $<0.15$ & $5 \cdot 25$ \\
\hline E. coli 12C & Glutathione & $1.0\}$ & $<0.10$ & $0 \cdot 20$ \\
\hline $\begin{array}{l}\text { E. coli 4-2 } \\
\text { E. coli 12C }\end{array}$ & $\begin{array}{l}\text { L-Cystine } \\
\text { Glutathione }\end{array}$ & $\begin{array}{l}1 \cdot 6 \\
1 \cdot 0\end{array}$ & $4 \cdot 5$ & $<0.15$ \\
\hline E. coli 4-2 & Glutathione & 1.2 & & \\
\hline E. coli $12 \mathrm{C}$ & L-Cystine & $2 \cdot 6$ & $<0.15$ & $<0.15$ \\
\hline
\end{tabular}

Table 2. Repression of sulphate-activating enzymes in E. coli 9723 and $K_{12}$

Extracts of $\boldsymbol{E}$. coli 9723 or $\mathrm{K}_{12}$ grown on glucose (0.067\%) plus glutathione $(0.21 \mathrm{~mm})$ or L-cystine (0.42 mM) were harvested (0.2-0.4 mg. dry wt. of cells/ml.) and assayed as described in Table 1 . An extract of $E$. coli 4-2 or $12 \mathrm{C}$ (each $1 \cdot 1 \mathrm{mg}$. of protein) grown on glutathione $(0.21 \mathrm{~mm})$ was added as indicated.

\begin{tabular}{|c|c|c|c|c|c|}
\hline Organism & $\begin{array}{l}\text { S source for } \\
\text { growth }\end{array}$ & $\begin{array}{c}\text { Amount of wild-type } \\
\text { extract added } \\
\text { (mg. of protein) }\end{array}$ & $\begin{array}{c}\text { Mutant extract } \\
\text { added }\end{array}$ & $\begin{array}{l}\text { Yield of APS } \\
(\mathrm{m} \mu \text { moles })\end{array}$ & $\begin{array}{l}\text { Yield of PAPS } \\
\quad(\mathbf{m} \mu \text { moles })\end{array}$ \\
\hline E. coli 9723 & Glutathione & $1 \cdot 4$ & - & $<0.15$ & $98 \cdot 4$ \\
\hline E. coli 9723 & L-Cystine & $1 \cdot 7$ & - & $<0.15$ & $<0.15$ \\
\hline E. coli 9723 & L-Cystine & $1 \cdot 7$ & E. coli 4-2 & $<0.15$ & $<0.15$ \\
\hline E. coli 9723 & L-Cystine & 1.7 & E. coli $12 \mathrm{C}$ & 6.0 & $<0.15$ \\
\hline E. coli $\mathrm{K}_{12}$ & Glutathione & $0 \cdot 6$ & - & $<0.15$ & $\mathbf{4} \cdot \mathbf{3}$ \\
\hline E. coli $\mathrm{K}_{12}$ & L-Cystine & 0.55 & - & $<0.15$ & $<0.15$ \\
\hline E. coli $\mathrm{K}_{12}$ & L-Cystine & 0.55 & E. coli 4-2 & $<0.15$ & $<0.15$ \\
\hline$E$. coli $\mathbf{K}_{12}$ & L-Cystine & 0.55 & E. coli $12 \mathrm{C}$ & $\mathbf{3} \cdot 0$ & $<0.15$ \\
\hline
\end{tabular}

unlike the subsequent ones involved in sulphate reduction (Pasternak et al. 1965), may be repressed in a co-ordinate manner (Ames \& Garry, 1959).

Control of sulphate activation in B. subtilis. It is probable that ATP sulphurylase and APS kinase are each repressed by growth on cystine (Table 4). The reason for the lower activity of sulphate-grown $B$. subtilis 1379 compared with that reported by Pasternak (1962) may be due to different compounds present in the current batch of broth. The composition of broth may also be the cause of the repressive effect of glutathione, which does not occur in $E$. coli growing in minimal medium. B. subtilis 3610, which grows well on minimal medium, was therefore investigated. Table 5 shows that in this strain glutathione represses to a variable extent in broth and actually de-represses in minimal medium. This result is compatible with the suggestion (Pasternak, 1962) that glutathione represses in $B$. subtilis 1379 because it is converted into cysteine faster than in E. coli.

Control of sulphate activation in D. desulphuricans and L. mesenteroides. Growth of D. desulphuricans in the presence of cysteine had little significant effect on ATP sulphurylase (Table 6). Sulphite, which theoretically might repress since the organism can be grown on it instead of sulphate (Table 6), was without effect.

It is generally accepted that organisms which require preformed amino acids for growth lack the necessary enzymes for their synthesis, though this is not always easy to demonstrate since most amino acids repress their own synthesis (e.g. Pardee, 1962). In cysteine biosynthesis it is possible to investigate this point with an organism whose cysteine requirement can be met by glutathione, which in minimal medium does not repress the enzymes of sulphate reduction (e.g. Tables 1, 2, 3 and 5; and Pasternak 
Table 3. Concentrations of ATP sulphurylase and APS kinase in E. coli 9723

Extracts of $E$. coli grown (0.16-0.46 mg. dry wt. of cells $/ \mathrm{ml}$.) on glucose $(0.075 \%)$ and the compounds indicated were assayed as described in the Materials and Methods section. ATP sulphurylase was measured in the presence of $\mathrm{CuCl}_{2}(1.25 \mathrm{~mm})$. The values quoted in the first row are the means of four or more experiments.

\begin{tabular}{|c|c|c|c|}
\hline \multirow[b]{2}{*}{ S source for growth } & \multicolumn{3}{|c|}{ Specific activity (m $\mu$ moles/mg. of protein/min.) } \\
\hline & ATP sulphurylase & APS kinase & $\mathrm{SO}_{4}{ }^{2-} \rightarrow$ PAPS \\
\hline \multirow[t]{2}{*}{ Glutathione $(0.21 \mathrm{~mm})$} & $\mathbf{2 \cdot 9}$ & $11 \cdot 3$ & $\mathbf{5} \cdot \mathbf{5}$ \\
\hline & \multicolumn{3}{|c|}{ Relative activity } \\
\hline Glutathione $(0.21 \mathrm{mM})$ & $(100)$ & $(100)$ & $(\mathbf{1 0 0})$ \\
\hline $\begin{array}{l}\mathrm{Na}_{2} \mathrm{SO}_{4}(4.2 \mathrm{~mm}) \\
\mathrm{Na}_{2} \mathrm{SO}_{3}(4.2 \mathrm{~mm}) \\
\text { L-Cystine }(0.042 \mathrm{~mm}) \\
\text { L-Cystine }(0.046 \mathrm{~mm}) \\
\text { L-Cystine }(0.052 \mathrm{mM}) \\
\text { L-Cystine }(0.056 \mathrm{~mm}) \\
\text { L-Cystine }(0.42 \mathrm{~mm})\end{array}$ & $\begin{array}{r}26 \\
4 \\
4 \\
2 \\
0.6 \\
<0.2 \\
<0.2\end{array}$ & $\begin{array}{c}25 \\
4 \\
10 \\
5 \\
0.4 \\
<0.2 \\
<0.2 ;<0.4^{*}\end{array}$ & $\begin{aligned} & 26 \\
& 2 \\
& 5 \\
& 2 \\
& 2 \\
& 0.6 \\
&<0.1 \\
&<0.1\end{aligned}$ \\
\hline
\end{tabular}

* Assayed spectrophotometrically with unlabelled APS.

Table 4. Repression of sulphate-activating enzymes in B. subtilis 1379

Extracts of $B$. subtilis grown in broth containing glucose $(0.5 \%)$ and the compounds indicated were harvested $(0.16-0.25 \mathrm{mg}$. dry wt. of cells $/ \mathrm{ml}$.) and assayed as described in Table 1 . An extract of $E$. coli $4-2$ (1.0 mg. of protein) or $E$. coli $12 \mathrm{C}(1 \cdot 1 \mathrm{mg}$. of protein) was added as indicated.

$\begin{array}{lcccc}\text { S compound added to } & \begin{array}{c}\text { Amount of wild-type } \\ \text { extract added } \\ \text { growth medium }\end{array} & \begin{array}{c}\text { Mutant extract } \\ \text { (mg. of protein) }\end{array} & \begin{array}{c}\text { Yield of APS } \\ \text { (m } \mu \text { moles) }\end{array} & \begin{array}{c}\text { Yield of PAPS } \\ \text { (m } \mu \text { moles) }\end{array} \\ \mathrm{Na}_{2} \mathrm{SO}_{4}(0.85 \mathrm{mM}) & 2.45 & - & <0.05 & 2.09 \\ \text { Glutathione }(0.85 \mathrm{mM}) & 2.6 & - & <0.05 & 0.28 \\ \text { L-Cystine (0.42 mM) } & 2.05 & - & <0.05 & 0.06 \\ \text { L-Cystine (0.42 mM) } & 2.05 & \text { E. coli } 4-2 & <0.05 & <0.05 \\ \text { L-Cystine (0.42mM) } & 2.05 & E \text {. coli } 12 \mathrm{C} & 2.38 & 0.06\end{array}$

Table 5. Sulphate activation in B. subtilis 3610

Cultures of $B$. subtilis were grown in broth or minimal medium as described by Pasternak (1962), harvested $(0 \cdot 1-0.8 \mathrm{mg}$. dry wt. of cells $/ \mathrm{ml}$.) and assayed for ability to synthesize PAPS. Different batches of broth were used for Expts. 1 and 2. The values quoted for minimal medium are the means of two experiments.

\begin{tabular}{|c|c|c|c|}
\hline \multirow[b]{2}{*}{ Growth medium } & \multirow{2}{*}{$\begin{array}{l}\text { S compound added to } \\
\text { growth medium }\end{array}$} & \multicolumn{2}{|c|}{$\begin{array}{l}\mathrm{SO}_{4}{ }^{2-} \rightarrow \text { PAPS specific activity } \\
(\mathrm{m} \mu \mathrm{moles} / \mathrm{min} . / \mathrm{mg} \text {. of protein) }\end{array}$} \\
\hline & & Expt. 1 & Expt. 2 \\
\hline $\begin{array}{l}\text { Broth } \\
\text { Broth } \\
\text { Broth }\end{array}$ & $\begin{array}{l}\mathrm{Na}_{2} \mathrm{SO}_{4}(0.85 \mathrm{~mm}) \\
\text { Glutathione }(0.85 \mathrm{mM}) \\
\text { L-Cystine }(0.42 \mathrm{mM})\end{array}$ & $\begin{array}{l}0 \cdot 09 \\
0 \cdot 07 \\
0 \cdot 14\end{array}$ & $\begin{array}{l}1 \cdot 12 \\
0 \cdot 47 \\
0 \cdot 18\end{array}$ \\
\hline $\begin{array}{l}\text { Minimal } \\
\text { Minimal } \\
\text { Minimal }\end{array}$ & $\begin{array}{l}\mathrm{Na}_{2} \mathrm{SO}_{4}(0.85 \mathrm{mM}) \\
\text { Glutathione }(0.85 \mathrm{mM}) \\
\text { L-Cystine }(0.42 \mathrm{mM})\end{array}$ & \multicolumn{2}{|c|}{$\begin{array}{l}2 \cdot 28 \\
9 \cdot 38 \\
0 \cdot 32\end{array}$} \\
\hline
\end{tabular}

et al. 1965). Such an organism is $L$. mesenteroides, and the sulphate-activating enzymes, PAPS reductase, sulphite reductase and serine sulphydrase were accordingly assayed (Pasternak et al. 1965) in extracts of cysteine-grown and glutathione-grown cultures. None of the enzymes could be detected, though other enzymes [cysteine desulphydrase (EC 4.4.1.1) and glucose 6-phosphate dehydrogenase 
Table 6. Concentration of ATP sulphurylase in D. desulphuricans

Extracts of $D$. desulphuricans grown in the presence of the compounds indicated were assayed as described in the Materials and Methods section. The values quoted are the means of two experiments.

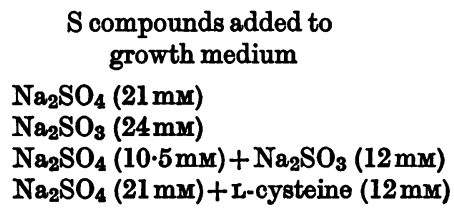

Extent of growth
(mg. dry wt. of cells/ml.)

0.23

0.11

0.11

0.03
Specific activity

( $\mathrm{m} \mu \mathrm{moles} / \mathrm{mg}$. of protein/min.)

0.67

0.92

0.79
(EC 1.1.1.49)] were present. The possibility that glutathione breaks down rapidly enough to yield an intracellular concentration of cysteine which represses cannot, however, be discounted.

The authors are indebted to Dr E. A. Davidson for supplying details of an unpublished method for preparing adenosine $5^{\prime}$-sulphatophosphate, and to the Rockefeller Foundation and the National Institutes of Health, U.S. Public Health Service (Grant no. A-3369), for financial support.

\section{REFERENCES}

Ames, B. N. \& Garry, B. (1959). Proc. nat. Acad. Sci., Wash., 45, 1453.

Balasubramanian, A. S. \& Bachhawat, B. K. (1962). Biochim. biophys. Acta, 59, 389.

Bornstein, B. T. \& Barker, H. A. (1948). J. Bact. 55, 223. Brüggemann, J., Schlossmann, K., Merkenschlager, M. \& Waldschmidt, M. (1962). Biochem. Z. 335, 392.

Butlin, K. R., Adams, M. E. \& Thomas, M. (1949). J. gen. Microbiol. 3, 46.

Cherniak, R. \& Davidson, E. A. (1964). J. biol. Chem. 239, 2986.

Davis, B. D. (1948). J. Amer. chem. Soc. 70, 4267.
Ellis, R. J., Humphries, S. K. \& Pasternak, C. A. (1964). Biochem. J. 92, 167.

Gibson, F. \& Woods, D. D. (1960). Biochem. J. 74, 160.

Gornall, A. G., Bardawill, C. S. \& David, M. M. (1957). In Methods in Enzymology, vol. 3, p.450. Ed. by Colowick, S. P. \& Kaplan, N. O. New York: Academic Press Inc. Gregory, J. D. \& Robbins, P. W. (1960). Annu. Rev. Biochem. 29, 347.

Monty, K. J. (1964). Abstr. Pap. Amer. chem. Soc., 146147th Meet., p. 42a.

Pardee, A. B. (1962). In The Bacteria, vol. 3, p. 577. Ed. by Gunsalus, I. C. \& Stanier, R. Y. New York: Academic Press Inc.

Pasternak, C. A. (1962). Biochem. J. 85, 44.

Pasternak, C. A., Crichton, C. E., Ellis, R. J., JonesMortimer, M. C. \& Wheldrake, J. F. (1964). Abstr. 6th int. Congr. Biochem., New York, p. 730.

Pasternak, C. A., Ellis, R. J., Jones-Mortimer, M. C. \& Crichton, C. E. (1965). Biochem. J. 96, 270.

Peck, H. D., jun. (1959). Proc. nat. Acad. Sci., Wash., 45, 701.

Peck, H. D., jun. (1962). J. biol. Chem. 237, 198.

Postgate, J. R. (1959). Annu. Rev. Microbiol. 13, 505.

Starkey, R. L. (1938). Arch. Mikrobiol. 9, 268.

Wilson, L. G. (1962). Annu. Rev. Pl. Physiol. 13, 201.

Wilson, I. G. \& Bandurski, R. S. (1958). J. biol. Chem. 233, 975. 